\title{
Being Günter Grass: Appropriations of the Tin Drum Author in the British Media*
}

\author{
Rebecca Braun
}

\begin{abstract}
Dieses Kapitel beschäftigt sich weniger mit der Rezeption des Blechtrommel-Textes als mit der seines Autors. Günter Grass wurde sowohl in englisch- als auch in deutschsprachigen Medien immer wieder als exzentrischer Blechtrommler dargestellt, und dies mehr als 50 Jahre nach dem Erscheinen seines berühmten Romans. Ausgangspunkt sind die unterschiedlichen, erheblich zeitversetzten Rezeptionskontexte der ,Weltautorschaft', die hier als bewusst performatives Erlebnis innerhalb der von Goethe definierten ,Weltliteratur' verstanden und mit Blick auf den amerikanischen und britischen Kontext der Grass-Rezeption erläutert wird. Insbesondere wird auf die britische Rezeption der letzten 25 Jahre seiner Karriere eingegangen, zunächst mit Blick auf die ersten Aneignungs- und Vermittlungsversuche der jüngeren britischen Autoren und Akademiker, die den ,Blechtrommler-Autor' in den goer Jahren einem breiteren Publikum vorstellten, und dann mit Blick auf die Kontroverse über das ,Israel-Gedicht" (2012). Dabei wird deutlich, dass sich Grass und die zunächst vorwiegend desinteressierte britische Medienlandschaft einander allmählich näher kommen, wenn auch über den Umweg der Metapher der Exzentrizität. Am Ende seines Lebens existiert ein überraschender Grad an Verständnis nicht nur für Grass, sondern auch für den ,public intellectual' (öffentlichen Intellektuellen) schlechthin.
\end{abstract}

Reflecting in the late 1980s on Grass's emergence onto the German literary scene some thirty years previously, Jürgen Manthey comments:

Die Kritik der ersten Stunde hat gespürt, mehr gespürt als erkannt, daß von hier eine 'Epoche' in der Nachkriegsliteratur ausging, wenn sie dies auch mit einem schiefen Vokabular beschrieben, mit falschen Akzenten versehen und widersprüchlichen Aussagen belegt hat. Den meisten war

* All data underlying this research are either published sources, as indicated in the bibliography, or were sourced from the Lexis newspaper archive available at $<$ http://www.lexisnexis. com>.

(C) REBECCA BRAUN, 2016 | DOI 10.1163/9789004291898_007

This is an open access chapter distributed under the terms of the CC-BY-NC License. 
Grass der Barbar im Garten, ein 'Kraftlatz', ein 'Beserker', ein 'literarischer Holzfäller' und 'poetischer Naturbursche', jedenfalls 'ein naiver Künstler'.

All dies war der Autor gerade nicht, sondern ein unglaublich disziplinierter, belesener, textbewußter [...] Schriftsteller [...]. Die Hinweise auf Vorgänger, Grimmelshausen voran, vertrugen sich jedoch mit Vorstellungen von 'kaschubischer Naturkraft', mit der ein 'literarischer Löwe' auf einmal 'in die Gefilde der Literatur einbrach, Hecken, Zäune und Gräben übersprang.'1

There is much one could say about this rich description of Grass's initial German reception. What is striking from a twenty-first century, Anglophone perspective, however, is the sense both of Grass's 'otherness' and his uncanny familiarity as an author operating in the German tradition. The superlatives that repeatedly figure in descriptions of the linguistic power and epic scope of his prose are simultaneously made to describe the author himself, who, with his distinctive moustache and origins in the far east of the old German Reich, gains further in allure as an unexpected insider-outsider figure. Furthermore, for all his apparent newness in the contemporary context, reviewers were quick to find literary precedents in the equally exotic, pre-Goethean age of Rabelais, Grimmelshausen, and Sterne. The author was widely felt to hail not just from another place, but also another time, compared to the bulk of his fellow post-war German writers. Not only does the outsider author figure thus arrive like a mythical 'gardener' or 'woodland clearer' who tends the very ground from which post-war German culture will grow, he also seems to bring potent fertilizer with him from the literary past, which he has, seemingly single-handedly, salvaged over three centuries.

The notion that one might come from a deeply German tradition and at the same time embody a radical critique of it is of course also the main conceit behind Grass's most famous protagonist, Oskar Matzerath. Without a doubt, the initial popular characterisations of the author of Die Blechtrommel referred to by Manthey were strongly influenced by the first-person account that Oskar gives of himself in his thoroughly distinctive narrative style. Cultural commentators' ongoing constructions of the text's real-life author as a radical 'Blechtrommler' figure himself, however, would exert a strong influence over the way Grass was perceived in Germany throughout the 1960s, as Franz Josef Görtz exhaustively demonstrates in his study from the 1970 s. $^{2}$ In fact, a tendency to elide the author with his literary characters in general, and Oskar in particular, has been a marked feature of Grass's reception across the entirety

1 Manthey (1988) 24.

2 Görtz (1978). 
of his German career; as late as 2006 he was portrayed banging a tin drum on the cover of Der Spiegel.

Significantly, one of the ways in which Grass has reflected on this oxymoronic positioning within his adopted (West) German cultural Heimat has been to enter into fictional conversation with Oskar at key points in his career. ${ }^{3}$ Between the mid-196os and mid-1980s, Grass was popularly seen to have abandoned the focus on the recent Nazi past for which he had first shot to public attention, and entered instead into an 'establishment' phase which was characterised by the author's highly vocal advocacy of a strong, ethically-informed engagement with national and global contemporary politics. This move made him increasingly unpopular with political and literary reviewers alike. Merging reflection on both his growing media unpopularity and his continued unease with the course of global politics, Grass reinstated a wildly experimental style and plot line in his 1986 Die Rättin / The Rat [1987]. One of the main strands of this novel revolves around Oskar Matzerath, who appears now as a media tycoon and argues extensively with his author-creator before the latter blows him up in the post-apocalypse world of his text. ${ }^{4}$ Grass did not make himself any more popular with this novel than his previous ones, but he certainly catered for ongoing controversy: a hostile spoof of the text, Der Grass, written by one Gunther Ratte, sold twenty thousand copies the year Die Rättin was released, amply documenting the ongoing ability of the self-identifying author of the Blechtrommel to provoke and annoy his fellow citizens. ${ }^{5}$

Ralph Mannheim's 1963 translation of Die Blechtrommel into the (American) English The Tin Drum introduced an Anglophone Günter (generally Gunter and sometimes Gunther) Grass to the world. Here too, the early literary reviews were cast in sensational tones. ${ }^{6}$ The Tin Drum was not the first translation of Die Blechtrommel - in fact, Siegfried Mews observes that the initial us interest in the text was fuelled by its European reception upon being translated into French. However, the hegemonic status of English is such that, once it had achieved high accolades in the Anglophone environment, its accession to the status of 'world literature' was largely guaranteed. ${ }^{7}$ Certainly, in terms of belonging in an academic canon of world literature, the statistical evidence provided by Henrik D.K. Engel implies that Grass quickly became a standard object of

3 On the notion of an evolving ,cultural Heimat' for West German writers, see Braun (2010).

4 For more on this, see the chapter on Die Rättin in Braun (2008).

5 Durzak (2000).

6 Mews (2008a) 17-18 gives a brief overview; excerpts from a wide range of American reviews can be accessed in White (1981).

7 On the significance of being translated into English, see Sapiro (2013); also quoted in Summers (2015). 
study across the Atlantic, while the sales figures for The Tin Drum speak for themselves: almost four hundred thousand copies were sold during the years 1963 and 1964 alone. $^{8}$

Britain too took notice of the author of The Tin Drum, in the form of a lengthy review of what would go on to be known as the 'Danzig Trilogy' in the Times Literary Supplement of 1963. This review was subsequently republished in a hard-bound book volume of $T L S$ literary reviews and essays that marketed itself as "an invaluable critical record of the most important books in many fields" in $1964 .{ }^{9}$ However, readily accessible primary material that documents the novel's initial popular reception in Britain is significantly scarcer than is the case for North America, for which a number of survey volumes and analytical essays are available. ${ }^{10}$ The searchable archives of The Times and The Guardian / Observer newspapers reveal just a handful of reviews of The Tin Drum / the Danzig trilogy in the early to mid-196os, with a similar number of author portraits that focus on the author's political 'drumming' becoming available in the latter half of the sixties. While the sources from the Times, the TLS, the Guardian, and the Observer all show clear appreciation for what makes Grass's first novel so innovative within the world of German letters, there is a distinct sense of the author's 'otherness' compared to his British peers. ${ }^{11}$ Thus the short review in the Times in 1962 observes that, while The Tin Drum has been a best-seller in Germany and France, "the English reader may be forgiven, perhaps, if it strikes him largely as an interesting but undisciplined work of a genuine but by no means major talent."12 This sense of the author's 'foreignness' in literary terms - whether connoted positively as innovative or negatively as undisciplined - is echoed in the slightly later descriptions of his political campaigning in 1965 and again in 1969. John Mander's reasonably lengthy 1969 portrait in The Guardian notes that Grass's books "have not sold well in England, lagging significantly behind their sales in America, Scandinavia, and France," while Eva Figes and Gudrun Tempel both point out that there is

$8 \quad$ Engel (2008) 10.

9 T.L.S. (1964), 67-71; marketing blurb is taken from the volume's inside cover. The other 'novels of 1963' reviewed in the volume are by: Henry de Montherlant, Carlo Emilio Gadda, V.S. Naipaul, Wilson Harris, Muriel Spark, David Storey, John Updike, Mary McCarthy, Kingsley Amis, Iris Murdoch, Ivy Compton-Burnett, Nathalie Sarraute, Alain RobbeGrillet, Cyprian Ekwensi, J.P. Donleavy. The review of Grass's 3 novels heads up this list (which is organised neither chronologically nor alphabetically and follows the order given here).

$10 \quad$ E.g. White (1981); O’Neill (1992); Mews (1999).

11 Anon (1964); Pendennis (1962); Leonhardt (1964).

12 Anon (1962). 
no imaginable British equivalent for the author in his active political engagement in 1965 and 1969 respectively. ${ }^{13}$

One of the few articles tracing Grass's ongoing distinctly British fortunes in the Anglophone world, Julian Preece's 1999 study of the author's impact on recent British writing presents Grass as an author's author, a figure who proved inspirational to the next generation of literary writers, but whose ability to inspire and shock is translated into a literary reception that necessarily unfolds over a longer period of time than is captured in immediate sales figures or book reviews. ${ }^{14}$ In the absence of hard data setting out Grass's initial media reception as the author of The Tin Drum in Britain, Preece's article provides useful proof of Grass's wider authorial discursive function in the British context. It shows the extent to which his authorial persona represents the impetus to provoke and innovate, as the British authors he inspired began to act on this impetus in the 1980s. It also perhaps explains the slight bewilderment with which Grass was met in the 1960 s by a media sphere that at that time simply had no home-grown comparison for him. Significantly, many of this later generation of writers, as well as academics such as John Reddick who first began introducing the author to British academe in the 1970s, would go on to write about or otherwise reference Grass in the British broadsheets of the 199os and 200os. This effectively sets up a pathway for the gradual appropriation of an author who, at the outset, was in every sense a rank outsider in the British literary field. The 2015 tributes to Grass that filled the British media on his death further underline this process. ${ }^{15}$

This longer-term reception of the author in the British media is the focus of the argument to be developed in the following pages. Work therefore remains to be done to collate the original material that could fill in the early British reception not just of The Tin Drum as a literary text but also Volker Schlöndorff's 1979 film of Books 1 and 2, which enjoyed considerable international success. ${ }^{16}$ My concern here is with the longer echoes of a work through its author, who has himself been constructed and re-constructed with reference to his first and most famous text over a career that spans more than fifty years and has garnered significant international acclaim. Ultimately it is this longer-term, cross-cultural resonance that validates the work as a piece of literature for posterity, while the changing ways in which the author has been positioned in respect of the work in turn condition its ongoing reception.

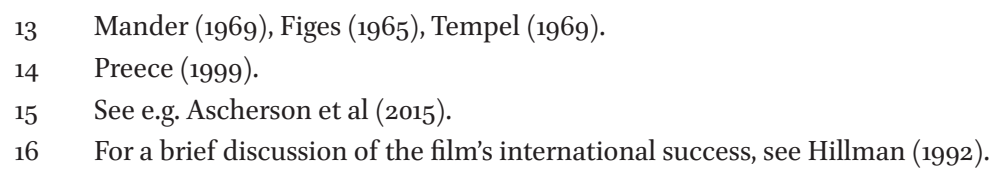


Grass's British reception has not only been slower than his reception elsewhere, it has also been out of step in other ways too. As his oeuvre has developed, a clear schism has become evident in what the author of Die Blechtrommel represents for his German readers and what his Tin Drum counterpart embodies for America on the one hand and for Anglophone Europe on the other. ${ }^{17}$ In the following, I shall attempt to explain not just why this schism came about, but also how Grass's specifically divergent British Anglophone reception has contributed to his own self-conception as the provocative insider-outsider author of Die Blechtrommel, which is in turn reprogrammed back into his writing. In order to do this, I shall underpin my argument with ideas about circulation and reception that have been developed in recent discussions of world literature. In so doing, I hope to shed light on the multiple ways of 'being' the creator of Oskar Matzerath that have conditioned Günter Grass's authorial existence in both Britain and Germany, but which also tell us something about the experience of world authorship more broadly.

\section{Günter Grass as a World Author: Diverging Experiential Models}

Subsequent to Johann Wolfgang Goethe's contested coinage in the early nineteenth century, 'world literature' has been variously understood as a canon of international (Modern) Classics, an elitist critical engagement with a Eurocentric concept of culture, a hopelessly idealistic attempt at cataloguing regional cultures, a depressing homogenisation of national cultures at the hands of global publishing houses, and, in a more upbeat move, a dynamic model for furthering postcolonial intercultural relations. ${ }^{18}$ These various evaluations are united by one striking aspect: their tendency to discount the actual author behind the literature under consideration. And yet, in declaring the

17 Although preliminary research for the article also included Grass's reception in the Republic of Ireland, there was not sufficient space to include this as a separate reception context here. I also did not feel that the trends in reception were sufficiently different to merit discrete analysis. On Grass in Ireland, see Fischer (2008).

For a useful overview of how the first two points have tended to predominate in constructions of world literature, see Hoesel-Uhlig (2004); Damrosch (2003) gives a very good sense of the common criticisms levelled at world literature. Both critics are ultimately arguing for an essentially positive, processual understanding of the term. Further essays shifting between world literature and comparative literature, particularly with regard to educational programmes, are collected in Saussy (2006). 
beginning of the "epoch of world literature,"19 Goethe was in many ways giving expression to a distinctly personal experience of what it means to write, read and be read within an increasingly globalised world. As David Damrosch states, for Goethe world literature was "less a set of works than a network,"20 and this network must surely have the writer at its centre. Goethe certainly valued the critical distance towards his own work afforded him by the 'mirrorings' of international reception, and he cherished the aesthetic lessons to be gleaned for his work from reading lesser-known literatures in translation.

Moreover, Manfred Koch has very persuasively argued that his very literary aesthetics are profoundly affected by his personal experience of cultural exchange. ${ }^{21}$ Such infectious enthusiasm for what Michael Minden has called 'literature as an international reality' can not only be traced to an author often credited with the beginning of modern German literature; it is intrinsically bound up with the emergence of modern day conceptions of authorship and autobiography, which theorists almost universally situate at the same point in time. ${ }^{22}$ Goethe's "epoch of world literature" significantly, and hardly by chance, coincides with a major recalibration of how authors exist and reflect on their existence in the public realm. Bearing this in mind, explicit consideration of what one could term the "epoch of the world author" is long overdue. ${ }^{23}$

Almost two hundred years after Goethe, Günter Grass invites sustained reflection on what the experience of world authorship might entail. He bears comparison to Goethe precisely in his positioning as an author both at home and abroad. This is not to draw parallels with regard to patterns of literary influence, self-identification with international literary greats, or actual canonical standing, although a case could probably be made for all three. What interests me here is the strong sense that both authors display of how, as authors, they are fundamentally shaped by the dynamic process of cultural transfer to which their works give rise. Damrosch's description of world litera-

19 Quotation (1827) from Goethe's conversations with Johann Peter Eckermann, cited in Damrosch (2003) 12.

20 Damrosch (2003) 3. For further reflection on the idea of cross-cultural literary engagement as a dynamic network, see the consideration of Greene (2006) of world literature in terms of comparative literature programmes currently compiled and taught in the us.

$21 \quad$ Koch (2002).

22 Minden (2008) 24. On the roots of modern authorship in Romanticism see Burke (1995). It has become standard to trace the roots of modern autobiography back to the same period; a representative approach can be found in Anderson (2001) and Nalbantian (1997).

23 For more thoughts on this, see the articles by John Noyes, Tobias Boes and Rebecca Braun in Braun (2015). 
ture as by definition in constant flux can equally, and perhaps even more accurately, be applied to the world authors who practise it: Goethe and Grass find their authorial personae subject to a "complex dynamics of cultural change and contestation." ${ }^{24}$ Within their own lifetimes both authors experienced their metaphorical transformation and commodification within a literary industry that developed a growing international dimension over their careers, and they have both reflected at length on this in their writing: Goethe in his very invention of the concept "world literature" as an epoch-defining moment, Grass, as this chapter will go on to explain, in the way he has reflected on his authorial presence in various different cultural contexts. ${ }^{25}$

The deliberate (re)-insertion of the "world author" figure back into "world literature" that I am proposing thus emphasises the experiential element of modern writing that has the writer as a historically and culturally situated agent at its core. Being a living world author of necessity always invokes a wider socio-political context. The importance of this point can be illustrated with reference to Grass's career directly. Analysing the us reception of the author's (at that point) thirty-year career, Patrick O'Neill uses the term "world author" as a label purely indicative of literary quality and shows how Grass, following the tremendous success of The Tin Drum, was quickly granted such a status in line with the predominant, depoliticised and text-focused understanding of "world literature" that characterised us perceptions of the time. ${ }^{26}$ The particularly American scholarly infrastructure of comparative literature programmes in academic institutions further supported this. Yet, as Siegfried Mews points out, even by the late 1960 s the American media were beginning to create a Günter Grass with a distinctly American socio-political significance: his introspective örtlich betäubt / Local Anaesthetic (1969/1970) was deemed to speak to and for a certain middle-class angst that had little to do with the situation of the German characters described in the book. When Grass started to look beyond the national German context and engage with global political and environmental concerns over the course of the 1980s, such appropriation turned into polarisation. The reception of his literary works both in Germany and the us became deeply coloured by reviewers' reactions to his political interventions. The more he took on the habitus of a living 'world author' whose global network goes far beyond patterns of literary influence to include contemporary people and policies, the more polemic he began to attract.

\footnotetext{
24 Damrosch (2003) 6.

25 On the comparative international contexts of the evolving literary industry in 19th and 21st century Germany, see Noyes (2015).

26 O'Neill (1992).
} 
While this resulted in significant controversy and rejection from literary traditionalists in the American context, the increased media coverage that Grass's direct engagement with (American-led) global politics afforded him also reinforced his presence in the American public sphere. Actively being a "world author" consciously situated in time and space not only energised Grass's US reception as both a literary author and a political commentator, but also brought it more into line with his controversial standing in Germany. ${ }^{27}$ For Grass, the experience of speaking out for his beliefs in a sometimes hostile political environment has allowed him to see himself through the eyes of others and come to a more conscious appropriation of his moral principles an appropriation intricately bound up with his self-perception as a public figure. $^{28}$

The social and historical specificities of Grass's national roots thus always affect not only how and why he engages with both his own and other nations, but also the way he experiences world authorship as an inherently political positioning in the contemporary world. As the American example shows, however, not just different cultures, but also different elites within those cultures, can have quite different expectations when it comes to an author's public presence. These can in turn significantly shape the image of his work and person that is refracted back to the author. The British engagement with Günter Grass shows notable divergences not just with his German authorial persona but also with his American one. It is both more detached, if not apathetic, when it comes to his wider cultural significance and, at the same time, more accommodating of the author's perceived 'quirks' and weaknesses.

\section{Günter Grass as the Author of The Tin Drum in the British Press: Irony, Apathy, and British-German Eccentricity}

While the German constructions of Grass as an exotic force revolutionising German literature from the margins began to wane over the course of the $1960 s$, to be replaced by creeping irritation with his 'establishment' political persona, the metaphors of shock and innovation retained their currency in Anglophone Europe. This was perhaps in part because of the second mediation through the next generation of British authors and academics referred to above. Both of these groups operated in the late twentieth century (and to a

\footnotetext{
27 Mews (1999). For an overview of how this increasingly politicized reception of Grass has informed his post-Nobel U.S. reception, see Mews (2008b).

28 See Brunssen (2008).
} 
considerable extent still do in the early twenty-first) in a literary and academic framework that is trained on national categories and the remnants of empire, rather than the comparative or world view that has characterised the North American literary sphere over the same timeframe. Consequently, Grass is presented less as a 'world author' along the American lines discussed above than as the 'foremost literary representative' of Germany and all things German.

The analysis of the press coverage that follows draws on the most pertinent twenty-two longer articles that a search through the Nexis database provided. ${ }^{29}$ Results were narrowed down from an initial search through all major British papers that referenced Günter Grass (and other orthographical variants of the author's name) in their title. It should be noted that, in purely quantitative terms, this number reflects a general lack of interest in the British media not specifically for Günter Grass, nor even for German-language writers more broadly, but for any non-Anglophone writer. Comparatively speaking, these twenty-two articles represent the nearest thing to a sustained and meaningful engagement with a non-Anglophone writer that the largely apathetic British media context can provide.

The recurrent approach taken to Grass as a 'German' author is apparent in a lengthy editorial in the Independent written in late 1990. The author is portrayed as a dizzyingly dynamic and deliberately non-conformist politicised individual who is the direct result of the German twentieth century. Significantly, consideration of Grass's literary output is couched in terms taken directly either from The Tin Drum or its more recent counterpart, The Rat. His 'novelistic world' is presented as "a world of dwarves and grotesques, of horses' heads on which eels feed, of demons and artists, talking rats, phallic trees." The emphasis on the shocking elements of Grass's literary writing in turn spills over into descriptions of his private life and geographical location: "Berlin too is a sort of frontier, and Berlin is where Grass has been living for some 30 years, in two houses: a Wilhelminian monstrosity, heavily peopled and kitchened; and his atelier, once the studio of a Schlachtenmaler, a painter of battle scenes, where he does his writing." ${ }^{30}$ With the reference to Berlin's peculiar geopolitical situation, and the double invocation of Germany's bellicose past in the Wilhelminian architecture and the studio's former 'battle-painter' occupier, Grass's private author person is rooted within an explicitly German context, as refracted through a British lens that remains permanently trained on World Wars I and II. The post-war socio-political paradoxes within this

29 My criteria were length (longer than 250 words) and focus of the article (Grass as the main focus of the article, rather than merely a passing reference within another context). 
context, however, constitute his ongoing allure for the British reporter. Just like the German characterisations from thirty years earlier, he is perceived as a kind of frontier figure, a gatekeeper between the fantastical and the real, the East and the West, and, in the context of the article's publication date, his country's recent past as a divided nation and its uncertain future as a unified entity.

Perhaps even more significantly, Grass is also presented as a public figure who has repeatedly failed in his attempts to make a tangible difference to the world, but he is applauded for his dogged determination to keep on trying nevertheless: "At 63, the walrus-moustached Grass, compact, bulky, untidy, hyperkinetic, would-be proletarian, deeply displaced person, seems as unremitting and protean as ever; words and images still pour from him." These images of excess and unruliness, framed as part of a positive drive to change German society for the better, map directly onto the terminology catalogued by Manthey in respect of the author of Die Blechtrommel in the late 195os and early 196os. In so doing, however, they entirely ignore the reality of Grass's German public persona in the intervening decades; he was repeatedly decried in the German media as an increasingly moralistic, out of touch, and self-satisfied commentator on national and international politics.

Where the links between the author and his most famous protagonist remain largely implicit in this profile, other descriptions are less subtle. They echo the German tendency of the 196os to elide the political campaigner with the literary drummer, whilst at the same time underscoring the ability of both to provoke. In 1997, the Guardian's satirical 'Pass Notes' offered a potted biography of the author that presents his literary significance entirely in terms of his shared background with Oskar Matzerath: "Born in Danzig; signed up by Hitler Youth; drafted at 16; wounded; PoW. After the war, he was a black marketeer, stonemason, jazz drummer, and art student. The success of The Tin Drum, which draws on his wartime experiences, established his reputation virtually overnight." Meanwhile, as a public figure, he is presented as the accessible exotic: "Sage, savant; cuddly version of Solzhenitsyn; pipe-smoker with prodigious walrus moustache" whose profession is "novelist, poet, thinker, scourge of bloated Western capitalism." ${ }^{31}$ Some of the glee that underpinned the original German reactions to him as a new and disruptive force within German literature still lives on in these ironically detached, British characterisations of the author as a colourful insider-outsider figure in his Central European context. The significance however, couldn't be more different. What was the subject of an exciting, polarising debate that swept through the German media in the 1960 s is now presented in the occasional British articles that engage with the

$31 \quad$ Anon (1997). 
author as a quirky, German phenomenon that ultimately underlines Germany's entertaining strangeness to the British reader.

Indeed, on the occasion of the award of the Nobel Prize to the author in 1999, Grass is repeatedly presented in the British press as an eccentric, toweringly disproportionate figure who is a thorn in his country's side - and therefore all the more scurrilous and entertaining as a result. In an article entitled "Gunter [sic] Grass joins literary giants: Controversial leftwing author of The Tin Drum becomes first German winner of Nobel accolade since 1972", Tony Paterson marks out a clear literary trajectory of increasing disappointment, as the Tin Drum is described as the defining moment of a career that, in literary terms, has not lived up to such early success. This apparent decline in literary standing is however compensated by the emergence of his colourful public persona: "The moustached, pipe-smoking author, who usually appears in public dressed in baggy cord trousers and tweeds, has evolved into both a grand seigneur of the German literary scene and an outspoken champion of human rights." ${ }^{32}$ Paterson's erroneous belief that Grass was awarded the Nobel Prize for the Tin Drum - based on focusing only on the first of the six paragraphs that constitute the official press release - is echoed throughout the English-speaking press. With this, the tweedy, pipe-smoking, ageing author is retrospectively telescoped onto the provocative voice and stature of his most famous literary progeny, with whom he first began winning German prizes forty years previously.

Such telescopic retrospective projection coupled with a drastic foreshortening of the post-Tin Drum development and reception of Grass's authorial persona repeatedly characterises post-Nobel Anglophone engagement with the author. Thus the longer articles published in the UK press in the fifteen years since his Nobel win standardly cover both his ur-Germanness and his bynow historical ability to disrupt and annoy as much as lead and inspire in both literary and political realms. Jonathan Steele's unusually long (c. 3500 words) 2003 portrait for The Guardian, for example, begins with a depiction of the author almost physically stepping back in time as he sets about his work in time-honoured style in rural Mecklenburg-Vorpommern:

Pipe between teeth and apron firmly tied, Gunter Grass crunches across the gravel from his remote two-storey farmhouse to the barn where his creative muses visit him. [...] He stands at a wooden lectern to compose his scripts in longhand or paces around the largely bare room mulling 
over the right word. Proud of his origins as a draughtsman, he says he likes the direct contact between hand, pen and paper. ${ }^{33}$

Yet, after directly linking Grass's beginnings as the author of The Tin Drum to his subsequent "typical stance [...] of a public gadfly, provocative, non-conformist, forcing his compatriots to examine themselves and their past, and enjoying the controversy he aroused", it also charts the author's growing isolation in the German context: "Grass remains an outsider and an exception in many ways. His new books are not read much by younger Germans, although The Tin Drum and Cat and Mouse are school-texts." 34

Indeed, this portrayal of the ur-German Grass as out of step with his country has become increasingly prevalent in both popular media coverage of the author and British literary criticism. The latter has developed the idea of a deliberately 'late style' in Grass's work, aligning him with the postcolonial thought of Edward Said. As both Karen Leeder and Stuart Taberner have shown, Said provides a way of understanding how idiosyncratic artistic work of the kind that Grass has produced in his later years tries to subvert prevalent cultural norms and hierarchies. ${ }^{35}$ Slippage into surprisingly quasi-colonial, if not deliberately ironic postcolonial, discourse is also evident in the press reporting on Grass's authorial person. The images of excess and semi-fantastical unboundedness referred to above are accompanied by an alternative coding of Grass as an isolated honorary British eccentric.

In his 2003 depiction of the ageing author, for example, Steele presents Grass as the relic of a lost age, still surviving in the north-eastern-most tip of modern Germany and moving in and out of synch with the country's government to a seemingly idiosyncratic schedule. Grass's ability to upset his compatriots has become an endearing, historicised quirk that attaches to him in his rural isolation, making him into a colourful, unpredictable old man who may come down on either side of popular prevailing ideologies. As a result, the challenging authorial position he embodies increasingly appears to lend itself to other national debates and contexts, made accessible to him through the reporting eyes and mouth of his British interlocutor. The more this British interlocutor directly reflects on the German author's eccentricities, the more the German author begins to transcend his ur-German context.

This characterisation was in fact also implicit in the earlier pieces, where the repeated emphasis on Grass's walrus moustache, pipe-smoking habits and

\footnotetext{
33 Steele (2003).

34 Steele (2003).

35 Leeder (2008); Taberner (2013).
} 
tweedy clothes must have made him appear like a turn-of-the-century, inverted English aristocrat straight out of Jeeves and Wooster to at least some of the papers' British readers. Now, however, his eccentricity is explicitly appropriated for the British context, to the point where Grass becomes a thorn in the side not so much of his own country, as of popular British nationalist sentiment. Thus Steele's article concludes with words of criticism from Grass directed at the un-self-critical British establishment: "I sometimes wonder how young people grow up in Britain and know little about the long history of crimes during the colonial period. In England it's a completely taboo subject.' [...] 'Look at Iraq. This conflict goes back to colonial history. Don't forget that."'

Grass's 'late' criticism of the UK is taken up in a number of subsequent articles. Also in 2003, the left-wing Morning Star quotes him criticising ideological blindness in the current labour government in an interview with the BBC, where he purportedly commented, "I sometimes have the feeling that Tony Blair follows the tradition of British colonial politics." What was quite possibly an aside in the interview is turned into the main thrust of this piece, as the journalist Amanda Kendal uses the statement as a hook on which to hang her challenge to neoliberal, British nationalist sentiment: "For as long as we maintain Germany as some global ubervillain, the unspoken perception of ourselves as global saviours remains. With that comes the implication that our rightful place is at the top table of global politics." ${ }^{36}$ By 2010, direct criticism of the UK has become Grass's USP. The headline for a long article in the Guardian review pages has him speaking directly to the British public: "A Life in Writing: Gunter Grass: 'In time, perhaps, your country will think about its colonial crimes. No country has the right to point only at the Germans. Everybody has to empty their own latrine." The outspoken comments are backed up by an image of the writer that emerges from the article as reliably off-key in his own country. Grass's move into English eccentricity is underscored by an actual linguistic shift towards English, as well as an unexpected display of humorous selfdeprecation:

His studio barn is next to the house he shares with his wife Ute, an organist. Downstairs he hammers on his blue Olivetti, and upstairs makes prints. With his 'walrus moustache' and pipe paraphernalia, Grass seems relaxed, switching between German and English - even mischievous. Rehearsing his objections to the 'annexation' of East Germany in 1990, he

$3^{6} \quad$ Kendal (2003). 
scowls theatrically, "you're speaking with an angry old man", but laughs with good humour. ${ }^{37}$

This kind of description relativises the reporting on his autobiographical revelations in Beim Häuten der Zwiebel of 2006, which made public the fact that he had served for a short time at the end of World War II in the Waffen ss, an elite fighting unit. This thoroughly unexpected confession ran throughout the international press in the late summer of that year, gathered in the UK, as elsewhere, comparatively short-lived, sensationalist attention, and was followed by a further, moderate ripple in 2007, when the English translation, Peeling the Onion, appeared. Unsurprisingly, those reports strengthened the link between the author and his most famous protagonist in their attempts to relay both the historical period and major biographical themes (shame, guilt, dishonesty) that are shared by the protagonists of The Tin Drum and Peeling the Onion. ${ }^{38}$

Such links, however, did not trigger any long-lasting wave of moral condemnation of the author by his British reviewers. Michael Hofmann predicted in 2007 that " $[\mathrm{t}]$ his lifelong silence, and the manner of his breaking it, have hurt Grass's reputation in ways from which it will never recover, and which, depressingly, he seems not even to have understood," but Hofmann's claims have not been borne out by posterity on either count. ${ }^{39}$ Quite to the contrary, the later UK media coverage of Grass not only gives him the space to reflect on how well he weathered that particular storm and to relativise the charges that were levelled against him. In the subsequent scandal that broke in 2012 around his poem on Israel, the British media goes beyond its ironic detachment and incipient apathy towards the curiosity that is Germany and its literature, and begins to devote a surprising amount of space to the notorious Tin Drum author Grass.

\section{Changing British Engagement with ‘World Author' Grass}

There is a far less well-developed culture of the public intellectual in Britain than in either Germany or North America, yet ironically it is in Britain that Grass's deliberate posturing as a politically provocative author of world renown seems to have met with the least resistance. Such comparative tolerance became evident when Grass simultaneously published the prose poem 'Was

37 Jaggi (2010).

38 See Gardam (2007).

39 Hofmann (2007). See also the tributes made to Grass on his death, e.g. Ascherson (2015). 
gesagt werden muß' ['What must be said'] in the Süddeutsche Zeitung, La Repubblica and El País in 2012. The poem hinges on the importance of Grass, now a world-famous German laureate who can be sure his words will be heard, shaking off the moral shackles of his birth to speak out against Israel's nuclear armament policy in the name of world peace.

For Thomas Steinfeld, who wrote explaining why the Süddeutsche Zeitung had published the poem but certainly did not defend it, the Nobel Prize in 1999 was the defining moment when Grass fully embraced his 'world author' status and turned himself into a "Aufseher der Weltpolitik“. This latest poem was just one more blatant example of how the work and person of Günter Grass were merging into one world-renowned, obscenely self-referential public figure. ${ }^{40}$ As if to underscore the growing convergence between negative German and negative American reactions to Grass as an overblown public intellectual, both the New York Times and Die Zeit pulled out of publishing the poem, on the grounds that none of their editors felt they could defend the author's position. Grass does not appear to have made any attempt to publish the poem in the British media, but, in the global furore that followed, it was reported upon at length in the UK, and an extract from the poem was published in translation by Breon Mitchell (who had just re-translated The Tin Drum) in the Guardian. For my media analysis, below, I narrowed down to forty-three articles the results of a Nexis database search of all 2012 UK newspaper articles that contained 'Gunter Grass' anywhere in the text. While the pieces were predominantly published in April 2012 (33 of the articles) and often only contain passing reference to the author, collectively they document a clear sense of the author's global newsworthiness on foot of the scandal caused by his poem. In various ways, this newsworthiness is more or less explicitly linked back to The Tin Drum.

Just as The Tin Drum provoked by breaking taboos, the poem was clearly designed to function as a provocative gesture. Unlike The Tin Drum, however, this gesture is not specifically inherent in the poem's content. The logic of the piece moves from why the author hasn't spoken out earlier (the general taboo surrounding German criticism of Israel), through why he is speaking out now (Germany's involvement in delivering nuclear missile launching submarines to Israel), to what he hopes to achieve (a transparent international programme of weapons inspection in both Israel and Iran). This is in itself a perfectly sound explanation of how Grass came to hold a certain political belief and decide to make it public. The provocation resides instead in the way Grass pitches the importance of this belief to the rest of the world. He effectively

40 Anon. (2012). 
demands a position of unassailable importance be accorded him on the basis of his lengthy literary and political experience, and he does this through two structural moves. These moves stem from the patterns of his Tin Drum authorship as they have been ritually reinforced over the years by the global media.

Firstly, by deliberately presenting his thoughts in the form of a poem by a Nobel laureate, Grass sets paratextual parameters that imply his words will carry some greater human truth, as is conventionally the stuff of literature, even in the mode of politically committed writing. Second, the strophes are all loosely structured around the dichotomy of remaining silent versus speaking out, such that the decision to move from one state to the next, together with some wider, but limited, reflection on the speaking context of this transition, is the main referent within the poem - the actual content of what is to be said is accorded far less space, so that when he does finally make some concrete points or recommendations, they fall flat. Such triumph of the medium over the message erases any final chance the poem may have had to function as a piece of protest literature. All that remains is the name and figure of Günter Grass himself, as he has been repeatedly encountered in global media coverage.

This is provocative play with the reader in the extreme. The author's words are important because he says they are, in a medium that says it is, across global media channels that know they are, not least because they can attract the most important cultural and political voices to fill their pages and thereby make the news. The circularity of this logic is unsurpassable. It can be read as the culmination of a programme of literary posturing that characterises Grass's 'late' work. However, questions of literary posturing can also be traced right back to Grass's very first literary work and his subsequent, world-wide reception as the provocative insider-outsider Tin Drum author who was believed to have much in common with his exhibitionist protagonist, Oskar (whose text, it might be noted in passing, also forms its own highly self-referential speech act). The extent to which the international media have sustained and re-cast this maverick author figure is surely the origin of Grass's belief that, simply by innovating in his use of literary form, he can and should provoke national and international debates that go well beyond literature.

To return to the British focus of this chapter, the insider-outsider status that Grass yet again very publicly claims for himself within the poem can, expanding on Steinfeld above, be seen as just the most recent manifestation of his particular 'world author' origins. As this chapter has shown, Grass's specific location as out of place, out of time, and out of synch with prevailing political orthodoxies is what made his 'brand' in the first place as the creator of Oskar Matzerath, both in Germany and abroad. However, beyond this general point, the poem and the furore it caused also further cemented his position in the 
British sphere as the eccentric Tin Drum author. Continuing the long-standing foreshortened reception of Grass as the author of The Tin Drum, most British reports on the poem take the novel, along with the 1999 Nobel Prize and the 2006 revelations about Grass's Waffen-ss membership, as their reference points for situating the author. However, they do so now in order to try to explain, very belatedly, first the broad political phenomenon and then the personal political contradictions of the public intellectual.

Nicholas Blincoe in The Telegraph is typical in this respect. Having glossed the controversies caused by the poem and by the Waffen-ss revelations and invoked Salman Rushdie's supportive words for Grass in both instances, the article plays its trump card in support of Grass: "The Tin Drum is the most serious and scorching German novel to cover the rise of Nazism and the war. This is why Grass won the Nobel prize."41 The fact that Grass wrote this novel over fifty years ago and gained official international recognition for it over ten years ago should, apparently, be enough to exonerate any political infelicities now. Almost the exact same wording appears in Jilly Reilly's more neutral feature in The Mail Online, as well as the anonymous report in The Telegraph from 8 April 2012. Among those who objected to Grass's poem, Robert Fine in The Guardian took exception specifically not to the points Grass was making about Israel's nuclear capacity, but to his creation of national stereotypes around his act of speaking out - the idea that a German who speaks out against Israel will automatically be branded an anti-Semite: "Through this assemblage of national categories, Grass lends the authority of the author of the magnificent The Tin Drum to the appalling notion that antisemitism is an issue that can and perhaps should be ignored - whether in Europe or the Middle East." In this case, Grass's authorship of The Tin Drum makes his later comments all the more unacceptable, since, Fine finishes his point, "Grass used to know better."42

Whether supporting or condemning the author for having written the poem - and collectively the British media remain relatively neutral on the whole affair - British journalists share a fundamental belief that Grass's authorship of The Tin Drum legitimates his commentary on global affairs in the first place. This represents a subtle but important shift from the portraits that were cast of the indefatigable ur-German of the 199os. Where these earlier reports celebrated the power of the author to shock and awe and actively embraced Grass's own presentation of his idiosyncrasies as part of his maverick author persona, the more recent reactions to the author begin to recast the achievements of both The Tin Drum and its author in much more specifically political,

\footnotetext{
$41 \quad$ Blincoe (2012).

42 Fine (2012).
} 
responsible terms. Consider in this context the description of Grass offered by Catrina Stewart on 9 April 2012 for The $i$ : "Best-known for his anti-war novel The Tin Drum, Grass was for decades seen as a leading moral authority in Germany for his criticism of his country's Nazi past, but his standing was badly damaged by the 2006 admission that he was drafted into the notorious ss in 1944 after being turned down for submarine service."43 This sober presentation of the writer as a "leading moral authority" and his most famous book as an "anti-war novel" has come a long way from the Independent's anonymous Rabelaisian portrait of the author in 1990, or even John Steele's engaging description of the otherworldly public gadfly in 2003 .

In a surprising twist, then, Grass's 'late' provocative enactment of his 'world author' persona has opened up a space, however small, in the British media to reconsider and reconnect with the decidedly twentieth-century, continental phenomenon of the public intellectual. ${ }^{44}$ Ironically, this is happening just as Germany and the us are administering the last rites to such a figure. ${ }^{45}$ Writing in October 2012 in The Scotsman after the dust had settled over Grass's poem, Allan Massie reflects directly on the divergent traditions of the public intellectual that become apparent when engaging with the work and person of Günter Grass:

Sometimes [Grass] may seem a little absurd to English-speaking readers. It is a long time, after all, since we decided there was no role for intellectuals, artists and mere writers in politics. The idea that politics should be the subject of intellectual argument rather than sound-bites and photoopportunities is regarded as ridiculously out-of-date. Even here in Scotland our arguments about the relative merits of independence or union are for the most part conducted in shallow and banal terms. There is little, if any room, for someone like Grass in the English-speaking world. Are we the better for this? ${ }^{46}$

It would be a step too far to suggest that Grass's increasingly global enactment of the public intellectual has done anything significant to alter the general lack

\footnotetext{
43 Stewart (2012). The gloss "author of the renowned anti-war novel The Tin Drum" also appears in anon (2012b).

44 For more on the British context of the public intellectual, see Collini (2006).

45 One of the key conclusions of the panel convened at the 2012 German Studies Association of America was that the role Grass was seeking to fill was now obsolescent. See the documentation in German Studies Review, 36 (2013).

46 Massie (2012).
} 
of British investment in the thoughts and actions of its (or any) literary elite. However, his experience of circulating as both a respected and a reviled subject of global newswires has without a doubt affected his own belief in the value of his public authorial persona, and over the past two decades the British media has engaged with this at some length. Grass's determination to embrace the opportunities that his world fame as the Tin Drum author has afforded him and to insert this authorial persona into multiple global political contexts has made him deeply unpopular in many of these contexts, not least in Germany. From the perspective of a country that has little to no tradition in this kind of politicised world authorship, however, Grass represents a model that seems so quirky and historical - so eccentric - that select voices within the British media have increasingly come out in support of the author where his allies elsewhere have all but vanished.

The inherently retarding gesture within the circulatory practice of world authorship that this chapter has been tracing thus emerges as the saving grace for the beleaguered national author of world renown. The "world author" position ascribed him by others is mutually experiential. It not only allows the culture that the author putatively represents to be experienced, at one remove, by a variety of detached onlookers who hail from a different time and place to the original text and its immediate wider public echo. The world author thus created can in turn also experience himself through the eyes of these diverse communities and, over the course of a career, appropriate for his own purposes the underlying media processes that drive these communities' self-perception. In the case of Günter Grass, this has been made manifest in his ongoing ability to command a global audience, however shaky the content of his later literary output and political opinions. Throughout his unpopularity in Germany of the 1990 s and early 200os, he has repeatedly found new and innovative ways of drawing international attention to the author's ability to offend - and thus be relevant to society - through the very act of writing and signing his name in public. 'Being Günter Grass' is clearly a risky business. However, in their very late acknowledgement of the contemporary political context in which the Tin Drum author has in fact always been operating, the twenty-first century British media have provided a surprisingly tolerant intellectual echo for this beleaguered German writer.

\section{Bibliography}

Anderson, L., Autobiography (London, 2001).

Anon., "New Fiction," in The Times, October 11, 1962. 
Anon., "Günter Grass: From Our Bonn Correspondent," in The Times, April 30, 1964.

Anon., "Profile: A citizen pugnacious in defeat; Gunter [sic] Grass, the un-unified German," in The Independent, December 1, 1990, 18.

Anon., "Pass Notes No.1107: Gunter Grass,"' in The Guardian, October 22, 1997.

Anon., "Anmerkungen zu Günter Grass: Dichten und Meinen," in Süddeutsche Zeitung, April 5, 2012, [accessed online 07.10.2014: <http://www.sueddeutsche.de/kultur/ anmerkungen-zu-guenter-grass-dichten-und-meinen-1.1326553>].

Anon., (2012b) "Israel bars German author Gunter Grass over poem," The Telegraph, April 8, 2012.

Ascherson, N., et al, "Günter Grass: The Man Who Broke the Silence," in The Guardian, April 18, 2015: [accessed online 22.04.2015: <http://www.theguardian.com/books/2015/ apr/18/gunter-grass-tributes-man-broke-silence $>$ ].

Blincoe, N., "Banning Günter Grass is Bullying Censorship," in The Telegraph, April 10, 2012.

Braun, R., "1967-2007: The Gruppe 47 as a cultural Heimat," in German Quarterly, 83/2 (2010), 212-229.

Braun, R. (2008), Constructing Authorship in the Work of Günter Grass (Oxford, 2008).

Braun R., \& F. Brunssen (2008) (eds.), Changing the Nation: Günter Grass in International Perspective (Würzburg, 2008).

Braun, R., \& A. Piper (eds.), "World Authorship and German Literature”, special issue of Seminar: A Journal of Germanic Studies, 51/2 (2015).

Brunssen, F., “Speak Out!' Günter Grass as an International Intellectual," in Braun \& Brunssen (2008), 94-115.

Burke, S., Authorship: From Plato to the Postmodern: A Reader (Edinburgh, 1995).

Collini, S., Absent Minds: Intellectuals in Britain (Oxford, 2006).

Damrosch, D., What is World Literature? (Princeton, 2003).

Durzak, M., "Grass Parodied: Notes on the Reception of Die Rättin," in M. Butler, and R. Evans (eds.), The Challenge of German Culture: Essays Presented to Wilfried van der Will (Basingstoke, 2000), 122-133.

Engel, H., Die Prosa von Günter Grass in Beziehung zur englischsprachigen Literatur: Rezeption, Wirkungen und Rückwirkungen bei Salman Rushdie, John Irving, Bernard Malamud u.a. (Frankfurt am Main, 1997).

Figes, E., "Grass Roots: An Interview with Gunter [sic] Grass, the German Writer and Politician," in The Guardian, November 12, 1965.

Fine, R., "Letter: Israel, Gunter Grass and the right to artistic licence," in The Guardian, April 9, 2012.

Fischer, J., "Knowing Your Grass from Your Elbow: Parameters of the Irish Reception of Günter Grass," in H. Kesting (ed.), Die Medien und Günter Grass (Cologne, 2008), 91-104. 
Gardam, T., "Confessions of a super Grass," in The Observer, June 24, 2007, 25. German Studies Review, 36 (2013).

Görtz, F., Günter Grass: Zur Pathogenese eines Markenbilds: Die Literaturkritik der Massenmedien, 1959-1969:Eine Untersuchung mit Hilfe datenverarbeitender Methoden (Meisenheim, 1978).

Greene, R., "Not Works but Networks: Colonial Worlds in Comparative Literature," in Saussy (2006), 212-223.

Hillman, R., "Film adaptations of Günter Grass's prose work," in S. Taberner (ed.), The Cambridge Companion to Günter Grass (Cambridge, 2009), 193-208.

Hoesel-Uhlig, S., "Changing Fields: The Directions of Goethe's Weltliteratur," in C. Prendergast (ed.), Debating World Literature (London/New York, 2004).

Hofmann, M., "Now I remember, now I forget: Michael Hofmann is dismayed by the tone and content of Gunter Grass's self-revelation," in The Guardian, July 7, 2007.

Jaggi M., "A Life In Writing. Gunter Grass: 'In time, perhaps, your country will think about its colonial crimes. No country has the right to point only at the Germans. Everybody has to empty their own latrine'," in The Guardian, October 30, 2010.

Kendal, A., "The Politics of Suffering," in Morning Star, April 23, 2003.

Koch, M, Weimaraner Weltbewohner: Zur Genese von Goethes Begriff 'Weltliteratur' (Tübingen, 2002).

Leeder, K., "Günter Grass's Lateness: Reading Grass with Adorno and Said," in Braun \& Brunssen (2008), 49-66.

Leonhardt, R., "The Nightmare Fairy-tales of Gunter [sic] Grass," in The Guardian, January $1,1964$.

Mander, J., "The Voice of German Democracy," in The Guardian, September 11, 1969.

Manthey, J., "Die Blechtrommel wiedergelesen," in H. Arnold (ed.), Günter Grass, 1 (Munich 1988), 24-36.

Massie A., "From Germany to Germany: Diary 1990 by Günter Grass", in The Scotsman, October 13, 2012.

Mews, S., Günter Grass and his Critics: From The Tin Drum to Crabwalk (Rochester, 2008).

Mews, S., "The Tin Drummer Marches on: The Post-Wende Reception of Günter Grass in the United States," in Braun \& Brunssen (2008), 170-183.

Mews, S., "Im Ausland geschätzt? Zur Grass-Rezeption in den USA,"' in Sprache im technischen Zeitalter, 152 (1999), 423-37.

Minden, M., “'Even the flowering of art isn't pure': Günter Grass's Figures of Shame," in Braun \& Brunssen (2008), 23-35.

Nalbantian, S., Aesthetic Autobiography: From Life to Art in Marcel Proust, James Joyce, Virginia Woolf and Anaïs Nin (Basingstoke/New York, 1997).

Noyes, J.K., "Writing the Dialectical Structure of the Modern Subject. Goethe on World Literature and World Citizenship," in Braun \& Piper (2015), 100-114. 
O'Neill, P., "A Different Drummer: the American Reception of Günter Grass," in W. Elfe, J. Hardin, G. Holst (eds.), The Fortunes of German Writers in America: Studies in Literary Reception (Columbia, 1992), 277-285.

Paterson, T., "Gunter [sic] Grass joins literary giants: Controversial leftwing author of The Tin Drum becomes first German winner of Nobel accolade since 1972," in The Guardian, October 1, 1999.

Pendennis, "Daylight: Tap on a Tin Drum for New German Writers," in The Observer, September 301962.

Preece, J., "Günter Grass und die britische Gegenwartsliteratur: eine Skizze," in Sprache im technischen Zeitalter, $15^{2}$ (1999), 438-54

Reddick, J., "Still banging the drum; German giant," in The Independent, October 3, 1999.

Sapiro, G., "Globalisation and Cultural Diversity in the Book Market:The Case of Literary Translations in the us and in France," in Poetics, 38 (2010), 419-439.

Saussy, H. (ed.), Comparative Literature in an Age of Globalization (Baltimore, 2006).

Steele, J., "Shaper of a nation's conscience: Gunter [sic] Grass," in The Guardian, March $8,2003$.

Stewart C., "Furious Israel bans Gunter [sic] Grass over Poem," in The i, April 9, 2012.

Summers, C., "World Authorship as a Struggle for Consecration: Translating Christa Wolf's Der geteilte Himmel," in Braun \& Piper (2015).

Taberner, S., Aging and Old-Age Style in Günter Grass, Ruth Klüger, Christa Wolf, and Martin Walser: The Mannerism of a Late Period (Rochester, 2013).

Tempel, G., "Drummer," in The Times, September 20, 1969.

T.L.S., Essays and Reviews from the Times Literary Supplement, 1963, vol.2 (London, 1964). White, R., Günter Grass in America: The Early Years (Hildesheim, 1981). 